\title{
Study of the Composition of Heavy Oil During the Simulation of Oil Displacement in Porous Media
}

\author{
Darya I. Chuikina*a, Vladimir V. Kozlov ${ }^{\mathrm{a}, \mathrm{b}}$, \\ Larisa D. Stakhina ${ }^{\mathrm{a}, \mathrm{b}}$ and Yuriy V. Savinykh ${ }^{\mathrm{a}, \mathrm{c}}$ \\ anstitute of Petroleum Chemistry, SB RAS \\ 4 Academichesky, Tomsk, 634055, Russia \\ ${ }^{b}$ National Research Tomsk State University \\ 36 Lenin, Tomsk, 634050, Russia \\ ${ }^{c}$ National Research Tomsk Polytechnic University \\ 30 Lenin, Tomsk, 634050, Russia
}

Received 11.07.2018, received in revised form 24.08.2018, accepted 06.09.2018

The effect of Enhanced Oil Recovery (EOR) system during the simulation of oil displacement in porous media in the laboratory on the composition of heavy oil from the Usinskoye oil field of Russia was investigated. It is shown that in the course of its displacement by water and surfactant composition from the model of reservoir of different permeability, 53-54 rel. \% of the residual oil remains on the core material. Using the methods of chromatography on silica gel in a Soxhlet apparatus and chromatomass - spectrometry (GC-MS) the changes of the component composition of oil passed through the pore space of rock sample (DOS) and those of non-recovered residual oil (ROS) were determined. It was found that the composition of the combined oil sample (DOS) after displacement by water, as well as with the use of compositions, is characterized by a slight increase in the alkane content (from 68 to $72 \mathrm{rel} . \%)$. The proportion of aromatic and naphthenic hydrocarbons in the sample of DOS in comparison with the original sample (MOS) decreased by an average of 1.2 times. In the residual oil (ROS) there is an increased content of resins and asphaltenes. The content of alkanes in the residual oil decreased by 3 times, while the total content of saturated cyclic hydrocarbons increased by 3.2-3.6 fold, aromatic compounds -2 times.

Keywords: heavy crude oil, EOR system, simulation, displacement, composition, asphaltenes, resins, hydrocarbons.

Citation: Chuikina D.I., Kozlov V.V., Stakhina L.D., Savinykh Yu.V. Study of the composition of heavy oil during the simulation of oil displacement in porous media, J. Sib. Fed. Univ. Chem., 2018, 11(3), 323-332. DOI: 10.17516/1998-2836-0078.

(C) Siberian Federal University. All rights reserved

* Corresponding author E-mail address: dichuikina@mail.ru 


\title{
Изучение состава тяжелой нефти \\ при моделировании нефтевытеснения \\ в пористых средах
}

\author{
Д.И. Чуйкина ${ }^{a}$ В.В. Козлов ${ }^{\mathrm{a}, \boldsymbol{\sigma}}$, \\ Л.Д. Стахина ${ }^{\mathrm{a}, \tilde{0}}$, Ю.В. Савиных ${ }^{\mathrm{a}, \mathrm{s}}$ \\ ${ }^{a}$ Институт химии нефти СО РАН \\ Россия, 634055, Томск, пр. Академический, 4 \\ ${ }^{6}$ Наџиональный исследовательский \\ Томский государственный университет \\ Россия, 634050, Томск, пр. Ленина, 36 \\ ${ }^{8}$ Национальный исследовательский \\ Томский политехнический университет \\ Россия, 634050, Томск, пр. Ленина, 30
}

Исследовано влияние методов увеличения нефтеотдачи (МУН) при моделировании вытеснения нефти в лабораторных условиях на состав тяжелой нефти Усинского месторождения России. Показано, что в результате вытеснения водой и композицией, включающей ПАВ, из модели пласта различной пористости на керновом материале остается 53-54 \% отн. нефти. Используя методы хроматографии на силикагеле в аппарате Сокслета и хромато-масс-спектрометрии (ГХ-МС), определили изменения компонентного состава нефти, прошедшего через поровое пространство образца горной породы (НПВ) и остаточного образцуа нефти (OH). Было установлено, что состав объединенной пробы нефти (НПВ) после вытеснения водой, а также с применением композиций характеризуется небольшим повышением содержания алканов (от 68 до 72 \% отн.). Доля ароматических и нафтеновых УВ в образие НПВ по сравнению с исходным образцум (МН) снизилась в среднем в 1,2 раза. В составе остаточной нефти (OH) наблюдается повышенное содержание смол и асфальтенов. Содержание алканов в остаточном образие нефти снизилось в 3 раза, тогда как суммарное содержание насыщенных ичиклических УВ увеличилось в 3,2-3,6 раза, ароматических соединений - в 2 раза.

Ключевые слова: тяжелая нефть, методы увеличения нефтеотдачи, моделирование, вытеснение, асфальтены, смоль, углеводороды, алканы.

\section{Introduction}

Decrease of resources of light crude oil on the earth leads to the extraction of heavy and extra heavy oils in recent years. The vast accumulations of heavy and extra heavy oil hold great potential, this oils are an abundant energy source. In recent years increasing worldwide energy demands and technology innovations have made heavy, extra heavy oils, oil sands and bitumen viable resources. 
More than $35 \%$ of the world's heavy oil resources are located in Venezuela and Canada, followed by the Middle East, US and Russia. Together, heavy oil, extra heavy oil, oil sands and bitumen account for about $70 \%$ of the world's total oil resources; heavy oil alone accounts for $15 \%$. Heavy oil reservoirs differ from one another, and the methods of recovery may vary considerably from one reservoir to another [1-3].

At present thermal methods of enhanced oil recovery (EOR) is an increasingly common method of extracting heavy and extra heavy crude oils worldwide. The main two forms of the technology for thermal stimulation of oil reservoirs are cyclic steam simulation and steam flooding $[4,5]$. The application of conventional methods of EOR, in particular that of thermal steam formation treatment results in a gradual decrease in the oil recovery factor due to an increase in the viscosity of fluids. This is associated with the oxidation of crude oil upon contact with water and the increase in the content of resin-asphaltene substances (RAS). Traditional processes of thermal steam treatment or water flooding of reservoir make it possible to extract on average only about $35 \%$ of the explored reserves, leaving 60 to $70 \%$ of crude oil in a reservoir $[6,7]$. The enrichment of this residual oil with RAS in the course of oil extraction is responsible for a decrease in well productivity. To assess potential reserves, it is necessary to carry out a quantity and quality control of residual oil after primary and secondary recovery, as well as an analysis of the composition and properties of oil displaced from the core material. The data obtained are used to develop strategies for recovering residual oil based on the use of new advanced technologies and methods of EOR using surfactant compositions often in combination with flow-diverging polymer solutions [8, 9]. Earlier, the effect of EOR methods on the composition of high-viscosity and heavy crude oils from Russia, Germany, and Mongolia has been studied under the laboratory conditions $[10,11]$. It was found out that the thermal treatment and the stimulation with EOR compositions cause significant changes in the composition and properties of the oils under study $[12,13]$.

Many researchers are steadily making attempts to find chemical additives to steam in order to improve its effect. Recently, there have been important progresses in oil recovery using chemical addition. At present carbon dioxide gas $\mathrm{CO}_{2}$ is considered as the best additive. The reasons of $\mathrm{CO}_{2}$ beneficial effect are well known: it increases phase permeability of a reservoir for oil, decreases oil viscosity etc. [14, 15]. Miscible carbon dioxide $\left(\mathrm{CO}_{2}\right)$ flooding has become the most commonly and favorable approach in Enhanced Oil Recovery (EOR) because of its high oil reservoir sweep efficiency and contribution to the reduction of greenhouse gas emissions. The results of $\mathrm{CO}_{2}$ gas injection revealed that the amount of pure asphaltene molecules deposition was increased to a great extent as the $\mathrm{CO}_{2}$ mole fraction was increased [16]. As well, in fields of Russia and Venezuela surfactant has been used to generate foams that enhance steam distribution more evenly in the reservoir $[17,18]$. The field tests in Henan Oil Field, China, using carbamide increased oil recovery by 7\% [19]. During some years many researchers are developing the concept of the treatment of high-viscosity oil pool with surfactant-based systems, which due to a heat carrier generate $\mathrm{CO}_{2}$ and ammonia buffer solution in situ [20, 21]. For the development of new EOR methods, fundamental research is needed, which is based on a comprehensive approach, including laboratory simulation of displacement processes, investigation of the composition and properties of filtered and residual oil (non-recovered after water flooding), and application of various technologies involving chemical reagents. 


\section{Experimental}

Oil samples. The bituminous heavy crude oil was sampled from the Usinskoye oil field (Komi Republic, Russia). The model of oil sample (MOS) for this system was represented by a mixture of $70 \mathrm{wt} \%$ of crude oil and $30 \mathrm{wt} \%$ of kerosene.

EOR compositions. As oil-displacing compositions served acid GBK composition based on glycerin, boric acid, surfactant and $\mathrm{N}-\mathrm{Z}$ composition based on alkaline buffer system, carbamide and surfactant. The acid GBK composition is used in 'cold' technologies for enhanced recovery of high-viscosity oils without thermal treatment of formation. The highly detergent N-Z composition was injected for the purpose of evaluating additional oil displacement after application of the GBK composition. The compositions were developed at the Institute of Petroleum Chemistry SB RAS [22, 23].

Simulation system. The oil-displacement process was investigated using an unit for studying filtration characteristics consisting of two steel parallel columns filled with a disintegrated core material (marble). Two columns of different permeability were used: $2.11 \mathrm{D}$ high-permeability column and that of $1.2 \mathrm{D}$ low-permeability.

The prepared columns were saturated with a model of formation water and their pore volume was measured. Then the model of oil sample (MOS) was filtered through the columns, displacing the water to form a water-oil-saturated reservoir model with a known oil saturation. A model of formation water was filtered through the resulted heterogeneous formation model in the 'formation-well' direction at an injection rate of $1 \mathrm{ml} / \mathrm{min}$ at $+23{ }^{\circ} \mathrm{C}$.

The filtration was continued until the water cutting of well production was completely achieved, and then the GBK composition in the volume equal to 0.5 pore volume of the model was injected in the 'well-formation' direction and held for 12 hours upon which the water displacement of residual oil was continued in the 'formation-well' direction.

Since then the process of cyclic steam treatment was simulated as follows: the heterogeneous formation model was heated to $+150{ }^{\circ} \mathrm{C}$ to filter a steam in the 'well-formation' direction in a volume equal to 0.3 pore volumes of the formation model and then held for 12 hours upon which the water displacement of residual oil was continued through the model in the 'formation-well' direction.

Thereafter, the N-Z composition was pumped in a volume of 0.5 pore volumes of the heterogeneous formation model in the same direction as the GBK composition. The level of exposure of water and oil-displacing compositions (GBK and N-Z) to the amount and composition of oil passed through the porous space of the rock model (DOS), as well as residual unrecovered oil (ROS) has been studied.

Method for removing water from oil samples. Before analysis, water should be removed from the sample by centrifugation. Sample of heavy crude oil and water are placed into a cone-shaped centrifuge tube. After centrifugation, the volume of the higher gravity water at the bottom of the tube is read.

The investigation of the composition of oil samples were carried out using a comprehensive approach, including the use of extraction methods, liquid-adsorption chromatography (SARA), IR spectroscopy, and chromatography-mass spectrometry.

Extraction method. The sample of residual oil (ROS) was extracted from core material with a hot mixture of alcohol : chloroform (7:93). 
SARA composition analysis. The content of the main SARA components (saturated and aromatic hydrocarbons, resins, and asphaltenes) was determined in the model oil sample (MOS) and in the samples of oil displaced by water and compositions (DOS), as well as in those of the residual oil sample (ROS). To separate asphaltenes, the weighed obtained samples were diluted with a 40 -fold excess of hexane and left for 24 hours. A precipitate of asphaltene was removed by filtration through a paper filter and then washed with hexane from co-precipitated resins and hydrocarbons (malthenes). Malthenes were separated by chromatography in a Soxhlet apparatus on silica gel. They were successively eluted with hexane in order to desorption saturated and aromatic hydrocarbons (SA-HCs), and with an alcohol: chloroform mixture (7:93) to isolate the resins.

IR spectroscopy. The IR spectra were recorded in a thin layer in the range $400-4000 \mathrm{~cm}^{-1}$ using a Thermo Scientific Nikolet 5700 FTIR Spectrometer equipped with a Raman module (Thermo Electron Corporation, USA). The spectroscopic coefficient, $\mathrm{C}$, is the ratio of the optical densities (D) of the characteristic absorption bands in the IR spectral region, which correspond to the respective types of bonds.

Chromatography-mass spectrometry. The individual and group composition of saturated and aromatic hydrocarbons was studied by gas chromatography-mass spectrometry (GC-MS) using a Thermo Scientific DFS magnetic-mass spectrometer. Identification of compounds was carried out using the data of 'NIST' Mass Spectral Library.

Individual groups of compounds were identified by their characteristic ions. To calculate the $\mathrm{S}_{\mathrm{i}}{ }^{\text {tic }}$ area of the identified compound using the total ion current, the formula 1 was used:

$$
\mathrm{S}_{\mathrm{i}}^{\mathrm{tic}}=\mathrm{k}_{\mathrm{i}}^{\mathrm{x}} \cdot \mathrm{S}_{\mathrm{i}},
$$

where: $\mathrm{k}_{\mathrm{i}}{ }^{\mathrm{x}}$ is the conversion factor for the identified compound, equal to the ratio of the peak intensity of total ion current for a compound to the ratio of the peak intensity of the characteristic ion for this compound;

$\mathrm{S}_{\mathrm{i}}$ is the peak area of the characteristic ion for the compound being identified.

To calculate the $\mathrm{X}_{\mathrm{i}}$ content (rel. \%) of the identified compound, the following formula was used:

$$
\mathrm{X}_{\mathrm{i}}=\frac{\mathrm{S}_{\mathrm{i}}^{\mathrm{tic}}}{\sum \mathrm{S}_{\mathrm{n}}^{\mathrm{tic}}} * 100 \%,
$$

where: $S_{i}^{\text {tic }}$ is the peak area in total ion current chromatogram for the compound being identified; $\sum S_{n}^{t i c}$ is the sum of the peak areas in total ion current chromatogram for all compounds identified.

\section{Results and discussion}

It was established by experiments that the process of oil displacement is different for low- and high-permeability columns. Thus, 35 vol. \% of oil was water displaced from a high-permeability column, while from that with a low-permeability only 30 vol. \% of oil (Fig. 1).

The effect of the composition results in additional 11 vol. $\%$ of oil displaced from a high permeability column and 17 vol. \% of oil washed from a low-permeability column. This is due to the fact that the bulk of the most mobile oil from the high-permeability column was located in the intergranular space, so it was displaced with water. The most part of additionally displaced crude oil 


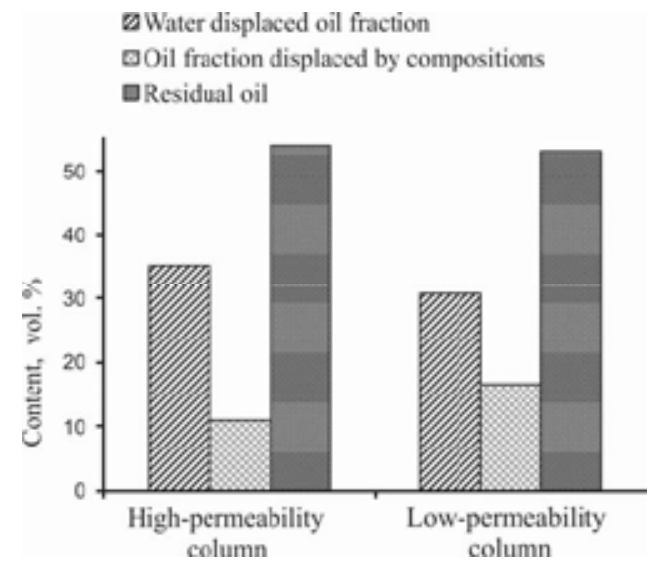

Fig. 1. Content of oil displaced by water and compositions from the core material and the content of residual oil for columns of different permeability

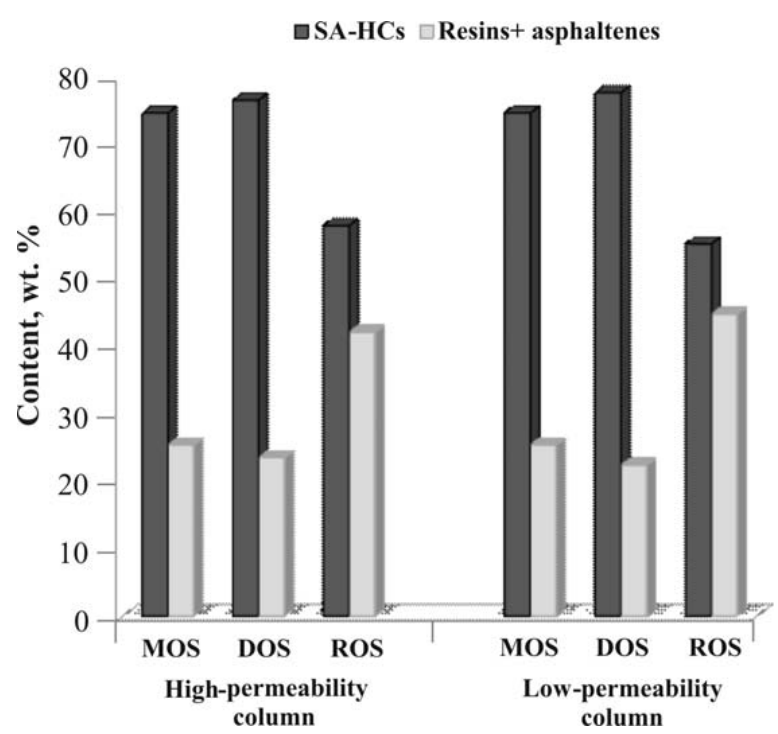

Fig. 2. Component composition of oil samples obtained at different stages of oil displacement from high- and low-permeability columns

were low-polar fractions, i.e. saturated and aromatic hydrocarbons (Fig. 2). The residual oil content for two columns was 53-54 vol. \% whatever their permeability.

The composition of the combined sample of oil recovered using water and oil-displacing compositions (DOS) had not changed substantially. The content of resin - asphaltene substances decreased on average by $10 \%$.

The changes in the composition of residual oil (ROS) compared to the initial MOS for each column are more pronounced and have a similar direction (see Fig. 2):

- the content of SA-HCs decreased by 1.3-1.4 times;

- the content of resins + asphaltenes increased by 1.5-2.3 times. 
Table 1. IR spectral coefficients

\begin{tabular}{|c|c|c|c|c|c|}
\hline \multirow{2}{*}{ Coefficient } & \multirow{2}{*}{ MOS } & \multicolumn{2}{|c|}{ High-permeability column } & \multicolumn{2}{c|}{ Low-permeability column } \\
\cline { 2 - 5 } & & DOS & ROS & DOS & ROS \\
\hline $\mathrm{C}_{1}$ & 0.15 & 0.18 & 0.30 & 0.19 & 0.39 \\
$\mathrm{C}_{2}$ & 0.89 & 0.82 & 0.47 & 0.81 & 0.37 \\
$\mathrm{C}_{3}$ & 0.07 & 0.09 & 0.00 & 0.11 & 0.00 \\
$\mathrm{C}_{4}$ & 0.56 & 0.58 & 0.58 & 0.57 & 0.58 \\
$\mathrm{C}_{5}$ & 0.11 & 0.12 & 0.22 & 0.13 & 0.25 \\
$\mathrm{C}_{6}$ & 0.12 & 0.14 & 0.21 & 0.16 & 0.24 \\
\hline $\mathrm{C}_{1}=\mathrm{D}_{1610} / \mathrm{D}_{1461}-$ the conventional ratio of aromatic structures to aliphatic structures; \\
$\mathrm{C}_{2}=\mathrm{D}_{820} / \mathrm{D}_{1610}-$ the conventional ratio of poly-substituted aromatic structures to their total content; \\
$\mathrm{C}_{3}=\mathrm{D}_{1710} / \mathrm{D}_{1461}-$ the conventional content of C=O groups of carboxylic acid; \\
$\mathrm{C}_{4}=\mathrm{D}_{1380} / \mathrm{D}_{1461}-$ the branching coefficient which characterizes the conventional content of $\mathrm{CH}_{3}$-groups; \\
$\mathrm{C}_{5}=\mathrm{D}_{1170} / \mathrm{D}_{1461}-$ the conventional content of ether groups; \\
$\mathrm{C}_{6}=\mathrm{D}_{1030} / \mathrm{D}_{1461}-$ the conventional content of sulfoxide groups
\end{tabular}

Thus, upon successive displacement of crude oil from the rock by water and surfactant solutions non-polar and low-polar components are displaced first. As a result, the content of resins and asphaltenes in a residual oil increased.

The IR spectra of the samples MOS and DOS show intense absorption bands of aromatic hydrocarbons within the range $1600-1615 \mathrm{~cm}^{-1}$, carboxylic acids at $1710 \mathrm{~cm}^{-1}$ and sulfoxides within the range 1040-1010 $\mathrm{cm}^{-1}$ (Table 1) .

Based on the IR spectrometry data, spectral coefficients were calculated. It is showed that the composition of the residual oil (ROS) differs markedly from that of initial and displaced oil. The composition of the samples ROS are enriched with aromatic, ether and sulfoxide groups (coefficients $\mathrm{C}_{1}, \mathrm{C}_{5}$ and $\mathrm{C}_{6}$ ). The branching of aliphatic chains (coefficient $\mathrm{C}_{4}$, reflecting the conditional content of $\mathrm{CH}_{3}$-groups) remains constant for all the oil samples under study. The content ratio of poly-substituted aromatic structures to their total number decreased due to the lower polarity of polyalkyl-substituted aromatic rings (coefficient $\mathrm{C}_{2}$ ).

It is evident from Table 1 that in the IR spectra of ROS the absorption band at $1710 \mathrm{~cm}^{-1}$ (coefficient $\mathrm{C}_{3}$ ) present in the spectrum of MOS was not observed here while intense absorption bands characteristic of the primary amides of carboxylic acids appeared at wavelengths $1662 \mathrm{~cm}^{-1}$.

This suggests that under the influence of ammonia formed during carbamide decomposition at $\mathrm{T}=+80^{\circ} \mathrm{C}$ the following reactions occur:

$\mathrm{CO}\left(\mathrm{NH}_{3}\right)_{2}+\mathrm{H}_{2} \mathrm{O}=2 \mathrm{NH}_{3}+\mathrm{CO}_{2}$ carbamide
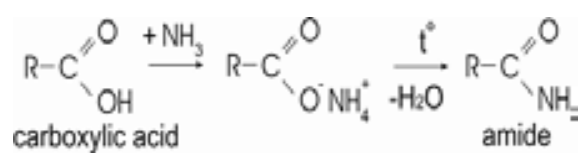

Carboxylic acids, as the most polar components of crude oil, are weakly desorbed from the mineral matrix and concentrated in residual oil (ROS), where they react with ammonia. 


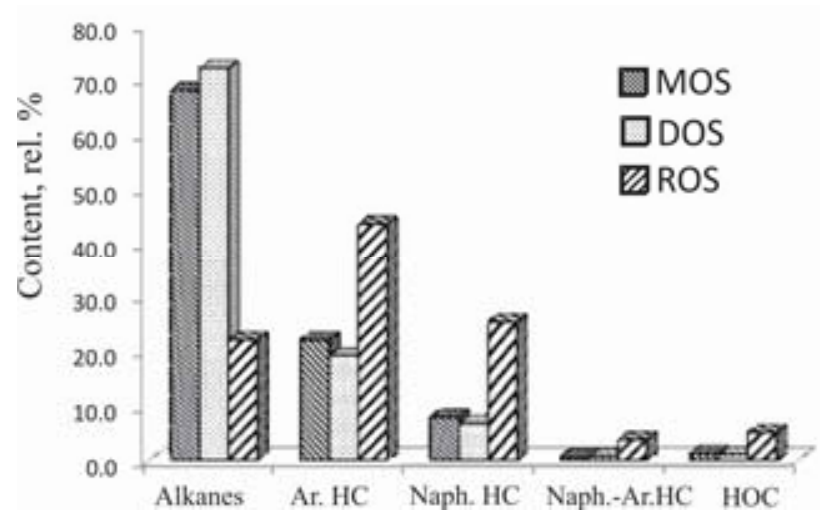

Fig. 3. Group composition of the SA-HCs from the samples: MOS, DOS and ROS Ar. HC - mono-, bi- and triaromatic HCs; Naph. HC - bi-, tri-, tetra- and pentacyclic saturated HCs; Naph.-Ar. HC - mono- and triaromatic steranes; Heteroorganic compounds (HOC) - all homologues of dibenzothiophene

The results of chromatography-mass spectrometry (Fig. 3) showed that the composition of the combined oil sample after water displacement, as well as after displacement by the compositions (DOS), is characterized by a slight increase in the content of alkanes (from 68 to 72 rel.\%).

The content of aromatic and naphthenic hydrocarbons in DOS decreased in comparison with the initial sample (MOS) on average by 1.2 times.

Analysis of the group composition of residual oil samples (ROS) showed more significant changes in the distribution of hydrocarbons.

Hence, the content of alkanes has been decreased by 3 times, while that of aromatic compounds has been increased by 2 times. As for aromatic compounds, the content of naphthalenes has been increased by 1.2-1.4 times, while that of phenanthrenes by 4.2-4.4 times and aromatic steranes by 6.8-7.8 times. The total content of saturated cyclic hydrocarbons has been increased by 3.2-3.6 times, while that of dibenzothiophenes by $4-4.3$ times in comparison with the initial oil sample (Fig. 3). The data on the content of aromatic hydrocarbons in composition of the residual oil sample obtained by the GC-MS method are confirmed by IR spectral coefficients (Table 1). It is noted that the changes in the composition of displaced and residual oil during laboratory simulation in porous media of carbonate rock are associated with the processes occurring in the formation such as sorption, filtration, the effect of chemical reagents and surfactant compositions used for enhanced oil recovery. Residual oil contains mostly high-molecular and high-polar components. During the interaction of the reagents of compositions with the crude oil secondary processes also occur, which result in a formation of new compounds.

\section{Conclusions}

1. The results of the experiments with model oil samples showed that after displacement by water and compositions during laboratory simulation, the core material contains 53-54\% residual oil both in low- and high-permeability columns.

2. It is found that the changes in the composition of residual oil (ROS) compared to the initial MOS for each column are more pronounced and have a similar direction. 
3. As a result in ROS the content of SA-HCs decreased by 1.3-1.4 times; the content of resins + asphaltenes increased by 1.5-2.3 times.

4. It is found that in ROS the content of alkanes was decreased by 3 times, while that of aromatic compounds was increased by 2 times.

5. The results obtained can be used to develop effectiveness criteria for heavy and extra heavy oil displacement systems studied.

\section{Acknowledgements}

Mr. Petr Kadichagov and Ms. Natalia Ryabova are thanked for support in analytical measurements (GC-MS, IR-spectroscopy analysis).

\section{References}

1. Meyer R.F., Freeman P.A. Siberian platform: Geology and natural bitumen resources: U.S. Geological Survey Open-file Report 2006. 24 p.

2. Meyer R.F., Attanasi E.D. and Freeman P.A. Heavy oil and natural bitumen resources in geological basins of the world: U.S. Geological Survey Open-file Report. Reston, Virginia. 2007. $36 \mathrm{p}$.

3. Hein Frances J. Heavy Oil and Oil (Tar) Sands in North America: An Overview \& Summary of Contributions. Natural Resources Research 2006. Vol. 15 (2), P. 67-84.

4. Donaldson E.C., Chilingarian G.V., Yen T.F. Enhanced Oil Recovery, II. Processes and Operations. Elsevier. Amsterdam, Oxford, New York, Tokyo. 1989. 594 p.

5. Santos R.G., Loh W., Bannwart A.C., Trevisan O.V. An overview of heavy oil properties and its recovery and transportation methods. Brazilian Journal of Chemical Engineering 2014. Vol. 31 (3), P. 571-590.

6. Nurgaliyev R.Z. Evaluation of advantages of the main technologies of oil displacement by water from heterogeneously permeabile oil reservoirs. Geology, Geophysics and Development of Oil and Gas Fields 2017. Vol. 10, P. 5-9.

7. Lafargue E. and Barker C. Effect of water washing on crude oil compositions. AAPG Bull 1988. Vol. 72, P. 263-276.

8. Babadagli T. Development of mature oil fields - A review, J. Petroleum Scientist and Engineering 2007. Vol. 57 (3-4), P. 221-246.

9. Turbakov M., Sherbakov A. Determination of Enhanced Oil Recovery Candidate Fields in the Volga-Ural Oil and Gas Region Territory. Energies 2015. Vol. 8 (10), P. 11153-11166.

10. Sherstyuk S.N., Serebrennikova O.V., Stakhina L.D., Kadichagov P.B. The effect of EOR technologies on the composition of recovered crude oil. J. Siberian Federal University. Chemistry 2010. Vol. 3 (2), P. 110-119.

11. Chuikina D., Serebrennikova O.V., Stakhina L.D., Nikolaeva T.L., Russkikh I.V. Laboratory Simulation of the Effect Oil-Displacement systems on the composition and properties of High-Paraffin Crude Oil. J. of Siberian Federal University. Chemistry 2011. Vol. 1, P. 11-17.

12. Chuikina D.I., Russkikh I.V., Stakhina L.D. and Serebrennikova O.V. Investigation of the Composition of High-Viscosity and Heavy Oils in the Course of EOR-Process Simulation. J. Siberian Federal University. Chemistry 2017. Vol. 2(10), P. 206-215. 
13. Stakhina L.D, Petrenko D.S. and Spabekova A.S. The Effect of EOR Technologies on the Content of Petroporphyrins and Naphthenic Acids of Recovered Heavy Oils From Usinskoye Field. Key Engineering Materials 2016. Vol. 670, P. 39-45.

14. Sheng J. Modern Chemical Enhanced Oil Recovery. Theory and practice. Gulf Professional Publishing, Elsevier, 2011. 632 p.

15. Zanganeh P., Dashti H., Ayatollahi S. Visual investigation and modeling of asphaltene precipitation and deposition during $\mathrm{CO}_{2}$ miscible injection into oil reservoirs. Fuel 2015. Vol. 160, P. 132-139.

16. Altunina L.K., Kuvshinov V.A. Enhanced Oil Recovery with Surfactant systems. Novosibirsk: Nauka, 1995. 198 p.

17. Valera C.A., Escobar M.A., Iturbe Y.J. Use of Surfactants in Cyclic Steam Injection in Bachaquero-01 Reservoir. 1999. SPE 54020-MS.

18. Zhang X., Zhang Y. et al. Conformance Control of CSS and Steam Drive Process with a Carbamide Surfactant. Journal of Canadian Petroleum Technology 2009. Vol. 48 (9), P. 16-18.

19. Thomas S., Farouq Ali SM. Status and Assessment of Chemical Oil Recovery Methods. Energy Sources 1999. Vol. 21, P. 177-189.

20. Luo P., Zhang Y., Huang S. A promising chemical-augmented WAG process for enhanced heavy oil recovery. Fuel 2013. Vol. 104, P. 333-341.

21. Alvarez J., Han S. Current Overview of Cyclic Steam Injection Process. Journal of Petroleum Science Research 2013. Vol. 2, P. 116-126.

22. Altunina L.K., Kuvshinov V.A. Physicochemical methods for enhancing oil recovery from oil fields. Russian Chemical Reviews 2007. Vol. 76(10), P. 971-987.

23. Altunina L.K., Kuvshinov V.A., Kuvshinov I.V. Gels, Sols and Surfactant Compounds Applied for Enhanced Oil Recovery at the Late Stage of Development. Georesources 2014. Vol. 4(59), P. 20-27. 